Borneo Journal of Sciences \& Technology, 3(2): 48-58

DOI: http://doi.org/10.3570/bjost.2021.3.2-09

e-ISSN: 2672-7439

(C) 2018, UCTS Publisher.

Submitted: $28^{\text {th }}$ December $2020 \quad$ Accepted: $28^{\text {th }}$ March 2021

Published: $31^{\text {st }}$ July 2021

\title{
Preliminary Study of Window-Opening Behaviour and Space Cooling Methods of Urban Households in East Malaysia
}

\author{
*Hirda Lailani Khalid and Mastura Bujang \\ University College of Technology Sarawak (UCTS), 96000 Sibu, Sarawak
}

\begin{abstract}
This paper presents the preliminary results of urban households' energy-use patterns in East Malaysia by assessing the window-opening behaviour and space cooling methods. A pilot survey was done with a random target of 30 urban or apartment households in Kota Kinabalu, Sabah, to fill the gap to represent the entire Malaysian data. The questionnaire was divided into five categories; socio-demographic and household types, house characteristics, house occupancy, window opening and space cooling methods, and satisfaction towards the living environment, and ownership of home appliances. The results revealed a slightly higher consumption for the apartment house despite most respondents from a family of four and the B40 income group. Air-conditioning (AC) system as the cooling method has been proven as a high contribution to this factor. An average of two AC units installed per dwelling resulted in RM198.39 or $661.3 \mathrm{kWh}$ of monthly consumption. Although $70 \%$ of respondents opened the window throughout daytime and night time, emphasised natural ventilation and fan usage most of the time, and majorly used the AC only during the night time. The uncomfortable feeling towards their indoor environment derived by the inappropriate building design has set a benchmark to occupant's tendency in restoring their comfort level regardless of their background.
\end{abstract}

Keywords: Energy-use behaviour, window-opening, space cooling, urban household

\section{INTRODUCTION}

Energy-use behaviour of urban residents varies among its occupants. Among the critical factors are the dwelling characteristics, indoor environment, home appliances ownership and usage, and its micro-climate (Arethusa et al., 2014; Kavaousian et al., 2013; Kubota \& Supian Ahmad, 2005; and Zaki et al., 2018). This behaviour can be easily observed from each dwelling's monthly electricity bill, representing the energy consumption affected by those factors.

In the tropical region, occupants used to rely on window opening to optimise passive ventilation to achieve thermal comfort. The hot and humid weather throughout the year with an average of $28^{\circ} \mathrm{C}$, low wind speed, and high humidity due to abundant rainfall make it a desirable condition and a great advantage for tropical occupants. However, this desirable condition is hardly achieved nowadays due to the urbanisations resulting in increasing density and populations each day.

In most cases, occupants tend to use any solutions to restore their comfort level (Humphreys et al., 2013), affecting the total energy consumption. The highest contribution towards the household energy consumption is from using the air-conditioning system
(AC) as the alternative cooling or a solution (Surahman $\&$ Kubota, 2012). The AC usage in Malaysian dwellings is significantly higher during nighttime to adapt to the uncomfortable condition that forced them to close the window, primarily due to the security and pollution factors (Arethusa et al., 2014).

Zaki et al. (2018) tested a methodology focusing on the usage of ACs in several high rise residential buildings in Kuala Lumpur. Similarly, it is concluded that the occupants in urban areas prefer to use ACs during the night when they inhabit the space after the time spent outside due to long working hours and other activities during the daytime. Moreover, it is also suggested that this preference is derived from the poor insulation of typical urban residential buildings that quickly transfer the heat inside, especially during the afternoon.

It could help the architects propose the most appropriate design by studying these factors, hence motivating them to optimise the passive ventilation. Furthermore, the study in energy use behaviour should focus not only on physical aspects but also on psychological factors. Therefore, this paper aims to investigate the significant contributors to energy consumption in the urban-dwelling in Kota Kinabalu,

Corresponding Author: Hirda Lailani Khalid. School of Built Environment, University College of Technology Sarawak (UCTS), Email: hirda.lailani@ucts.edu.my 


\section{Preliminary Study of Window-Opening Behaviour and Space Cooling Methods of Urban Households in East Malaysia}

Sabah, which hypothesised to be the window opening behaviour and the aids of space cooling such as air-

\section{Geographical Location}

Previous studies mainly involved selected cities in West Malaysia, such as Kuala Lumpur (Zaki et al., 2018) and Johor Bahru (Kubota \& Supian Ahmad, 2005 \& Kubota et al., 2011). However, the gap was found in the lack of study in Malaysia's other part to represent the data entirely. Thus, this preliminary study focuses on the survey in the city of Kota Kinabalu, Sabah. It is one of Malaysia's two states in East Malaysia, separated by the South China Sea from 11 states in West Malaysia (Fig.1).

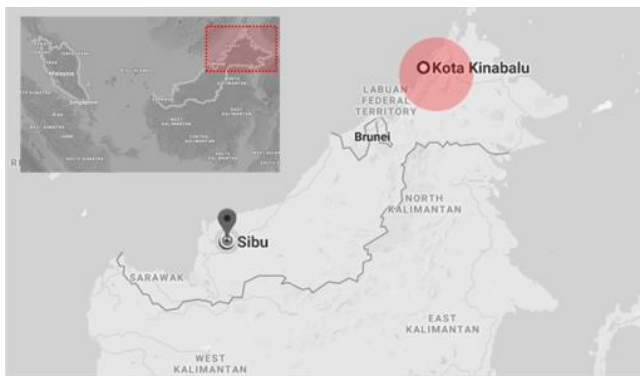

Figure 1. The location of Kota Kinabalu on the map of Malaysia and Borneo (Source: Google Maps)

Two apartment buildings which are Harrington Suites (high-end apartment), and Taman Penampang Apartment (4-story medium-cost), were selected in this study in consideration of the high-density residential area as the worst-case scenario (Fig.2). The summary of the survey profile is shown in Table 1.

Table 1. The general profile of preliminary surveys conducted Kota Kinabalu

\begin{tabular}{|c|c|c|}
\hline Apartment & $\begin{array}{c}\text { Harrington } \\
\text { Suites }\end{array}$ & $\begin{array}{c}\text { Taman } \\
\text { Penampang }\end{array}$ \\
\hline Respondents & \multicolumn{2}{|c|}{30} \\
\hline \multirow{2}{*}{ Type } & High-end & Medium cost \\
\cline { 2 - 3 } & 30 -storey & 4-storey walk-up \\
\hline Constructed & $2011-2017$ & $2000-2010$ \\
\hline
\end{tabular}

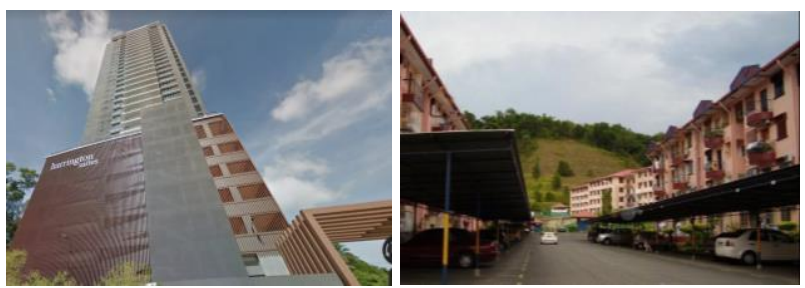

Figure 2. (Left) Harrington Suites; (Right) Taman

Penampang Apartment (Source: Google) conditioning system and fan.

\section{METHODOLOGY}

The data is collected by using a quantitative method and analysed by using simple frequency analysis, as below:

\section{Survey and Interview}

Thirty households were randomly accessed from these two apartments by a face-to-face interview between February 2018 and March 2018. The overall questionnaire survey was designed to extract the information of occupants' energy use and consumption based on five sections:

a) Part1: Socio-demographic and household types: Family type, total numbers of occupants based on age group category and employment;

b) Part2: House characteristics: Apartment type, heat protection, window type;

c) Part3: House occupancy, window opening, and airconditioning usage: Energy consumption based on the occupancy of spaces;

d) Part4: General satisfaction for the living environment: Households' perception of the condition of the indoor environment;

e) Part5: Home appliances ownership: Cooling, personal gadgets, cleaning, cooking, telecommunication, monthly electricity bills.

\section{Data Analysis}

The data from questionnaire surveys were analysed by using the frequency method as follow:

a) Part1: Total number, frequency (\%) and mean;

b) Part2: total number, frequency (\%), and mean;

c) Part3: Pattern of AC and fan usage and window opening based on occupancy on an hourly basis;

d) Part4: Frequency and mean of the household's condition in the indoor environment;

e) Part5: Frequency and mean of home appliances ownership.

As a whole, the expected result is treated as an initial projection of data in East Malaysia.

\section{RESULTS AND DISCUSSION}

\section{Part I: Socio-demographic Profile}

Table 2 summarises the socio-demographic information of respondents. The criteria are categorised into (i) household size, (ii) household types, (iii) total number of working and non-working households, (iv) age group of working households, and (v) their average 


\section{Preliminary Study of Window-Opening Behaviour and Space Cooling Methods of Urban Households in East Malaysia}

monthly income. According to several studies, the household energy consumptions are majorly contributed by the household size and types, the total number of working and non-working households, and the average monthly income (Tanimoto \& Hagishima, 2010; Zaki et al., 2018; Fragidis and D. Olschewski, 2015). Hence, these variables were tested similarly in this study.

Table 2. Socio-demographic profile

\begin{tabular}{|c|c|c|}
\hline Socio-demographic & Details & $\begin{array}{l}\text { Frequency } \\
\qquad(\%)\end{array}$ \\
\hline Sample size & 30 (104 households) & 100 \\
\hline \multirow[t]{6}{*}{ Household size } & 1 & 3.3 \\
\hline & 2 & 23.3 \\
\hline & 3 & 23.3 \\
\hline & $4^{*}$ & 30.0 \\
\hline & 5 & 13.3 \\
\hline & 6 & 6.7 \\
\hline \multirow[t]{6}{*}{ Household types } & Working adult (1 person) & 3.3 \\
\hline & Working adult and housewife ( 2 persons) & 23.3 \\
\hline & Working adults and children ( $>3$ persons $)^{*}$ & 30.0 \\
\hline & Working adults and child / all working adults ( $>3$ persons) & 23.3 \\
\hline & Working adults, parents and children (>4 persons) & 13.3 \\
\hline & $\begin{array}{l}\text { Working adults, housewives, and children / Working adults, parents, } \\
\text { children }\end{array}$ & 6.7 \\
\hline \multirow{5}{*}{$\begin{array}{l}\text { Number of non- } \\
\text { working households }\end{array}$} & Adult & 28.8 \\
\hline & School children* & 51.9 \\
\hline & University/ Pre-U & 9.6 \\
\hline & Toddlers/ babies & 9.6 \\
\hline & Total: 51 persons & 44.5 \\
\hline \multirow{4}{*}{$\begin{array}{l}\text { Number of working } \\
\text { households }\end{array}$} & 1 & 36.7 \\
\hline & $2 *$ & 50.0 \\
\hline & 3 & 13.3 \\
\hline & Total: 53 persons & 55.5 \\
\hline \multirow[t]{6}{*}{ Monthly income } & $<\mathrm{RM} 1 \mathrm{~K}$ & 6.7 \\
\hline & RM1 - 2K & 35.6 \\
\hline & RM2 - 3K* & 37.7 \\
\hline & RM3 - 4K & 20.0 \\
\hline & RM4 - 5K & 2.2 \\
\hline & $>$ RM5K & 2.2 \\
\hline
\end{tabular}

The survey shows the average size of households is 3.47 (Figure 3), which is much lower than Statistics Malaysia 2016 due to the small sample size and assessed on only two residential areas. The average size of households in Malaysia is four, and Sabah is slightly higher with 5.5. The primary or nucleus family type of "two working adults and children family" is identified as the significant household type from the sample with $30 \%$. It is typical to see this household type in the compact urban dwellings and smaller in size in the majority of urban areas to accommodate a higher number of households. The percentage of working and non-working households are found to be 55.5 and 44.5, respectively. Most of these non-working households consist of housewives, parents or other relatives (extended family) with $28.8 \%$ and school children in primary or secondary school with $51.9 \%$ (Figure 4).

For the household income, the highest percentage ranges between $\mathrm{RM} 2,000$ and $\mathrm{RM} 3,000$ with $35.6 \%$. It resulted in an average income per household of 2.86 , which falls in group 3 (Figure 5). It is comparable with the Statistics Malaysia 2016 with RM2,860, categorised as B40, the bottom $40 \%$ or lower class under Malaysia's income classification. The monthly electricity bills 
(Figure 6) revealed that most respondents have an average of RM150.00 with $21.4 \%$ and the mean of RM198.39. The SESCO electricity tariff is projected an average consumption of $661.3 \mathrm{kWh}$ per month. It is considered higher consumption for the apartment buildings than the data obtained by Ahmed et al. (2017), which revealed the monthly usage of the only $451 \mathrm{kWh}$

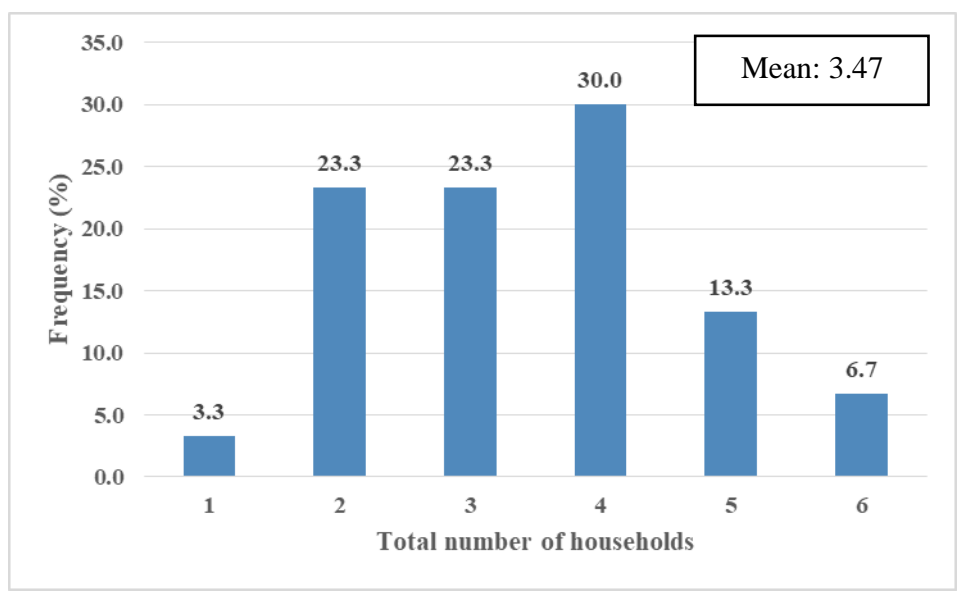

Figure 3. Total number of households

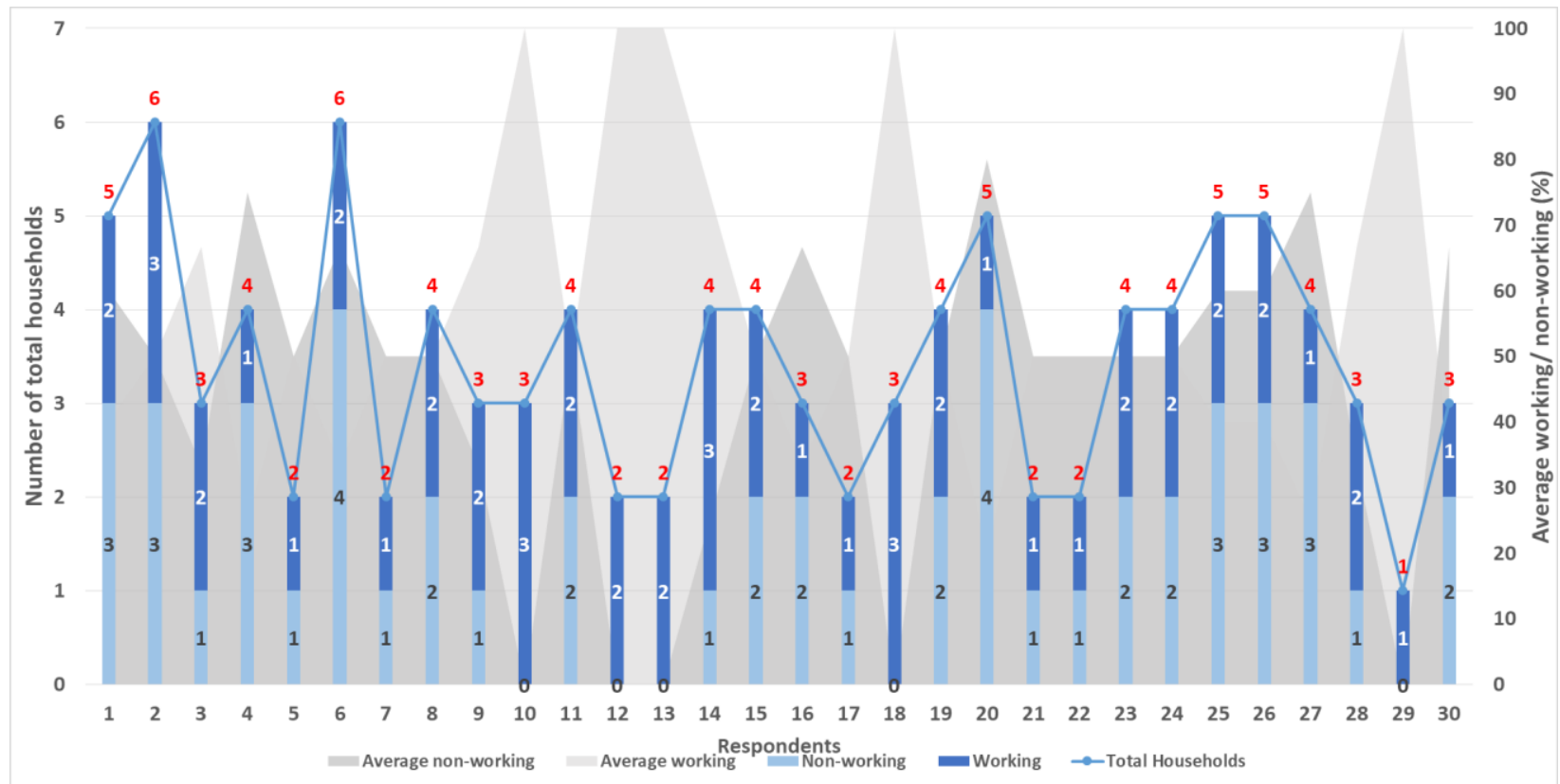

Figure 4. Total household, average household size, and a total of working and non-working households 


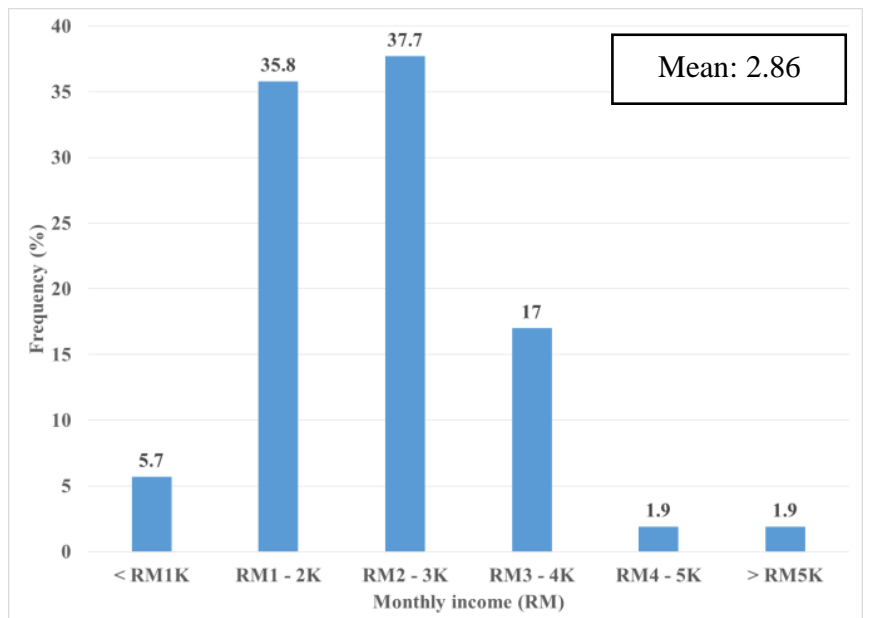

Figure 5. Percentage of average monthly income for total households

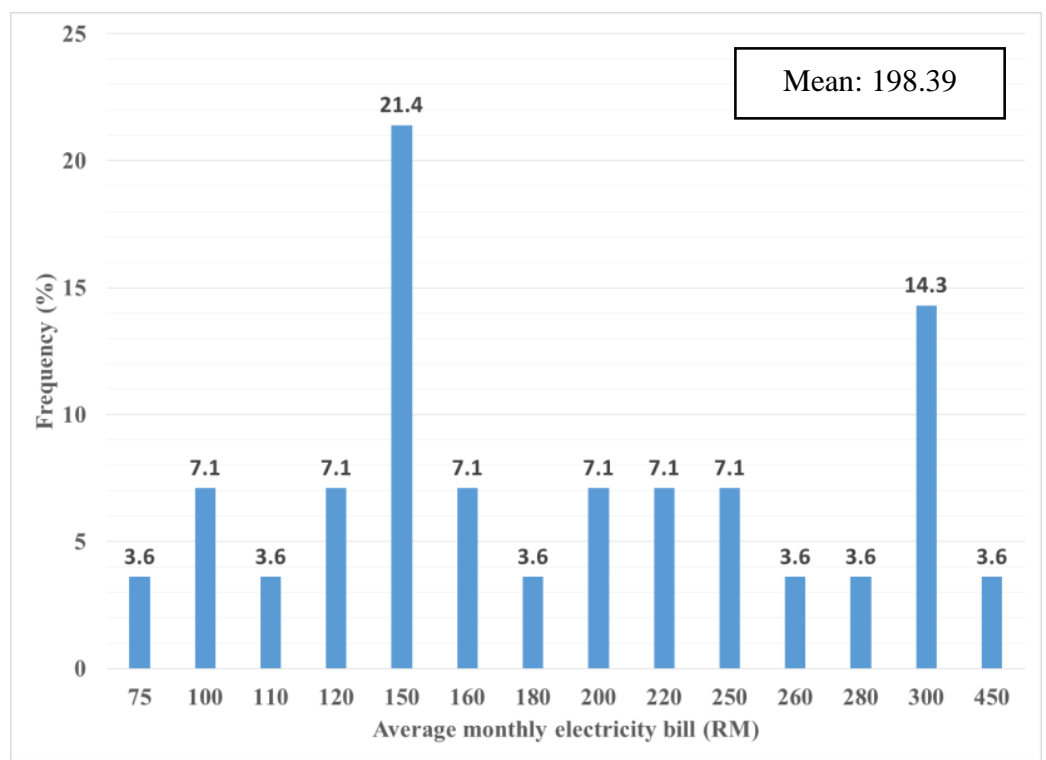

Figure 6. The average monthly electricity bill for all households

\section{Part II: House Characteristics}

The existing house characteristics for both apartments are summarised in Table 3. The Harrington Suites units are much bigger than Taman Penampang as it has four bedrooms and is considered a high-end apartment. To suit the contemporary concept as the current design, most areas are covered with glazing but still incorporate the openable window and big sliding door to the balcony area. However, this envelope enhances more heat gain to the units facing north-east and south-west orientation even with concrete overhang and metal-mesh provided as sun-shading devices. On the other hand, Taman Penampang is a three-bedroom walk-up flat without lift and consists of a few blocks. Several blocks are facing south-east, and several more are facing north-west orientation. Technically, both orientations have a maximum exposure to sunlight that could be affecting the indoor environment and its occupants.

The details for house ownership, major opening orientation and additional indoor protection based on individual units are summarised in Table 4. About $79.3 \%$ of the respondents owned the house they are currently staying. An equal percentage of $10.3 \%$ is renting the house with family and $10.3 \%$ with nonfamily members (colleagues, friends, or random persons). The majority of units are oriented towards the north-east with $56.7 \%$ and $43.3 \%$ towards the southwest. Occupants tend to make extensive efforts to protect the internal space from external factors. $73.3 \%$ units are installing with curtain, $13.3 \%$ are using blind 


\section{Preliminary Study of Window-Opening Behaviour and Space Cooling Methods of Urban Households in East Malaysia}

and tint film and another $13.3 \%$ use the combination of curtain, blind and tint film.

Table 3. Existing house characteristics for both apartments

\begin{tabular}{|l|l|l|}
\hline Characteristics & Taman Penampang & Harrington Suites \\
\hline Type & Walk-up, without lift, blocks & High-rise with lift, single block \\
\hline Floor area & $1000-1200$ sqm & $>1400$ sqm \\
\hline Orientation of front facade & South-east, north-west & North-east \\
\hline Total bedrooms & Three & Four \\
\hline Type of windows & Glass-sliding & Glass-casement, Glass-fixed \\
\hline External sun shading & Short concrete overhang & Concrete overhang, metal-mesh \\
\hline Fixed-ventilation panel & Top-hung louvred & NA \\
\hline Type of door & Panel, glass-sliding & Panel, glass-sliding \\
\hline
\end{tabular}

Table 4. Ownership, individual house characteristics

\begin{tabular}{|l|l|l|}
\hline \multicolumn{1}{|c|}{ Characteristics } & \multicolumn{1}{|c|}{ Details } & \multicolumn{1}{c|}{ Frequency (\%) } \\
\hline \multirow{4}{*}{ House ownership } & Owned & 79.3 \\
\cline { 2 - 3 } & Rent with family & 10.3 \\
\cline { 2 - 3 } & Rent with non-family & 10.3 \\
\hline \multirow{2}{*}{ Major opening orientation } & North-east (NE) & 56.7 \\
\cline { 2 - 3 } & South-west (SW) & 43.3 \\
\hline \multirow{2}{*}{ Additional protection } & Curtain & 73.3 \\
\cline { 2 - 3 } & Blinds + tint film & 13.3 \\
\cline { 2 - 3 } & Curtain + blinds + tint film & 13.3 \\
\hline
\end{tabular}

\section{Part III: House Occupancy, Window Opening and Space Cooling Methods}

Figure 7a shows that the average occupancy during nighttime for weekdays, weekends, and public holidays is higher than the daytime by $3.9 \%$. Total numbers started to decrease significantly after $8.00 \mathrm{am}$ and started to increase again after $2.00 \mathrm{pm}$. During this period, most occupants (82.4\%) went out for work, school, and other activities, as $51.0 \%$ of them were working adults and $31.4 \%$ were school children and university (Table 2).

The window opening's average duration is 18.6 hours daily, with the highest frequency between 6.00 am and 11.00 pm (Figure 7b). From Figure. 8, it was revealed that the main factors that affected the respondents' tendency to open the window as much as possible during the daytime are to cool the indoor environment $(48.3 \%)$, besides to get the fresh air (20.7\%) and emphasises the natural lighting (17.2\%) (Figure 8). Among the reasons their tendencies to close the window during nighttime are due to privacy $(37.9 \%)$, security $(13.8 \%)$, protection from insects $(13.8 \%)$ and the use of $\mathrm{AC}(13.8 \%)$.
On the AC usage (Figure 7c), the lowest use was during the afternoon (below 40\%), where it started to decrease from $2.00 \mathrm{pm}$ until $5.00 \mathrm{pm}$ before gradually increasing. The highest frequency can be observed during night time from $10.00 \mathrm{pm}$ until 12.00 am with more than $50 \%$. The usage started to reduce after midnight with some fluctuations. It is a similar result obtained by Zaki et al. (2017) that most Malaysian prefer to use AC during night time, especially before the sleeping hours. However, this part needs a more detailed investigation in the field measurement on the $\mathrm{AC}$ daily usage and the temperature set-point to support this research project's outcome. On average, AC usage was $38.1 \%$ or 9.1 hours daily.

Figure $7 \mathrm{~d}$ shows the respondents' daily fan usage. In general, the total daily use was almost throughout the day, with an average of $60 \%$ for weekdays, weekends and public holidays. The highest fan usage was recorded between $12.00 \mathrm{pm}$ and $5.00 \mathrm{pm}$ as most nonworking households consisted of housewives, and their children occupied the house during that period (Figure 4). Their preference to use natural ventilation and fan aid is in line with the result of a window opening (Figure 7b) and AC usage (Figure 7c). 

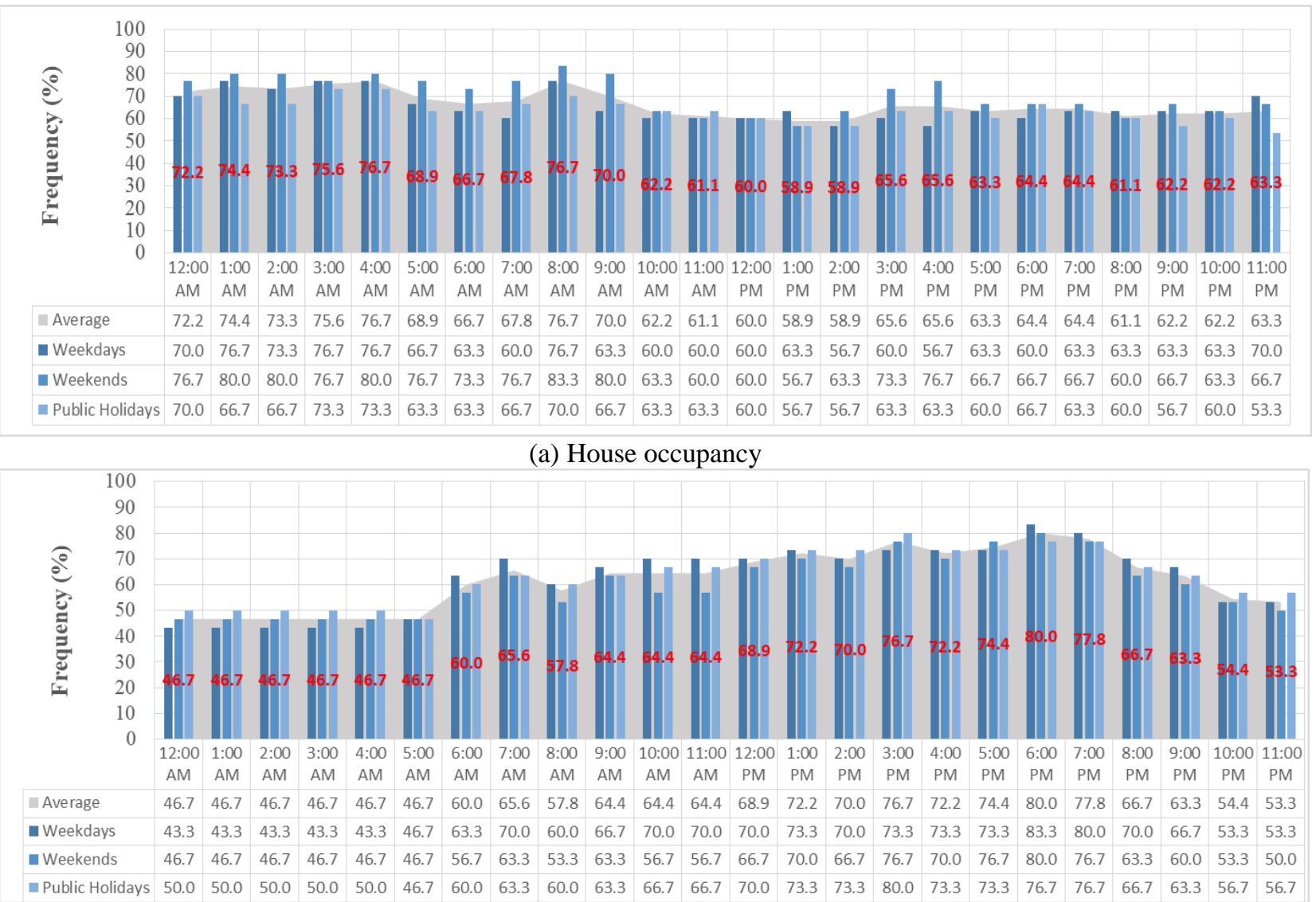

(b) Window opening

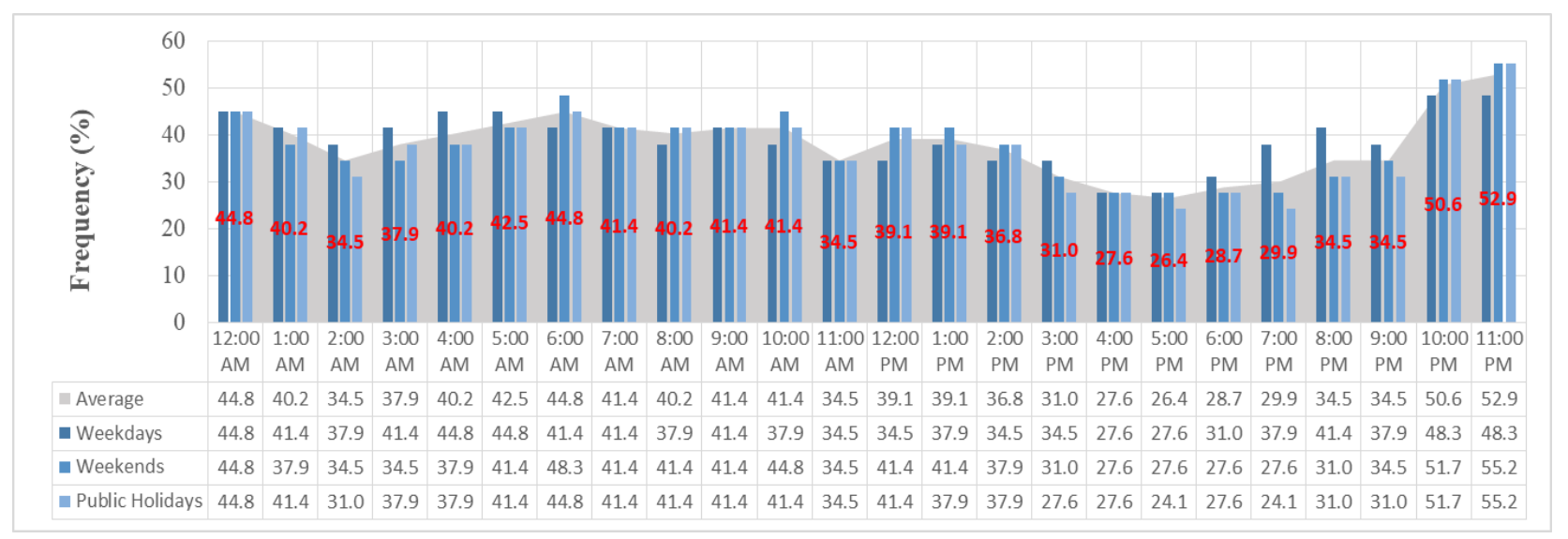

(c) AC usage 


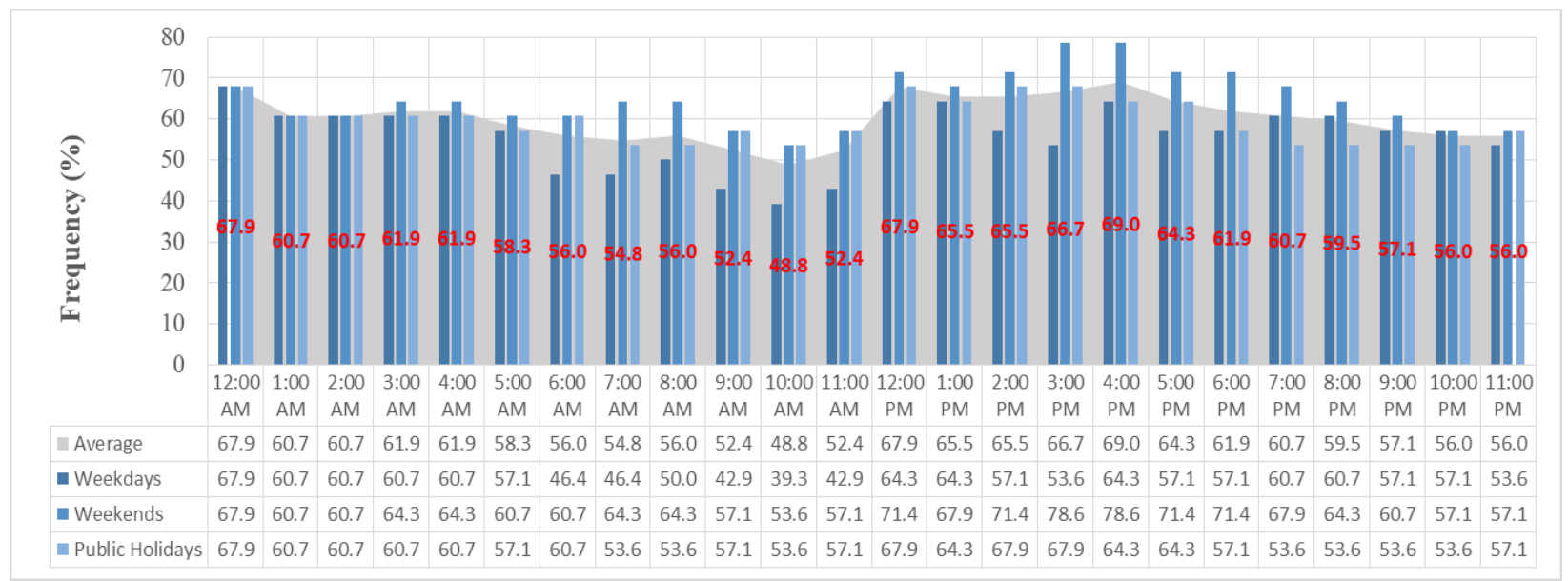

(d) Fan usage

Figure 7 (a, b, c, d). Comparison of house occupancy, window opening, AC usage and fan usage
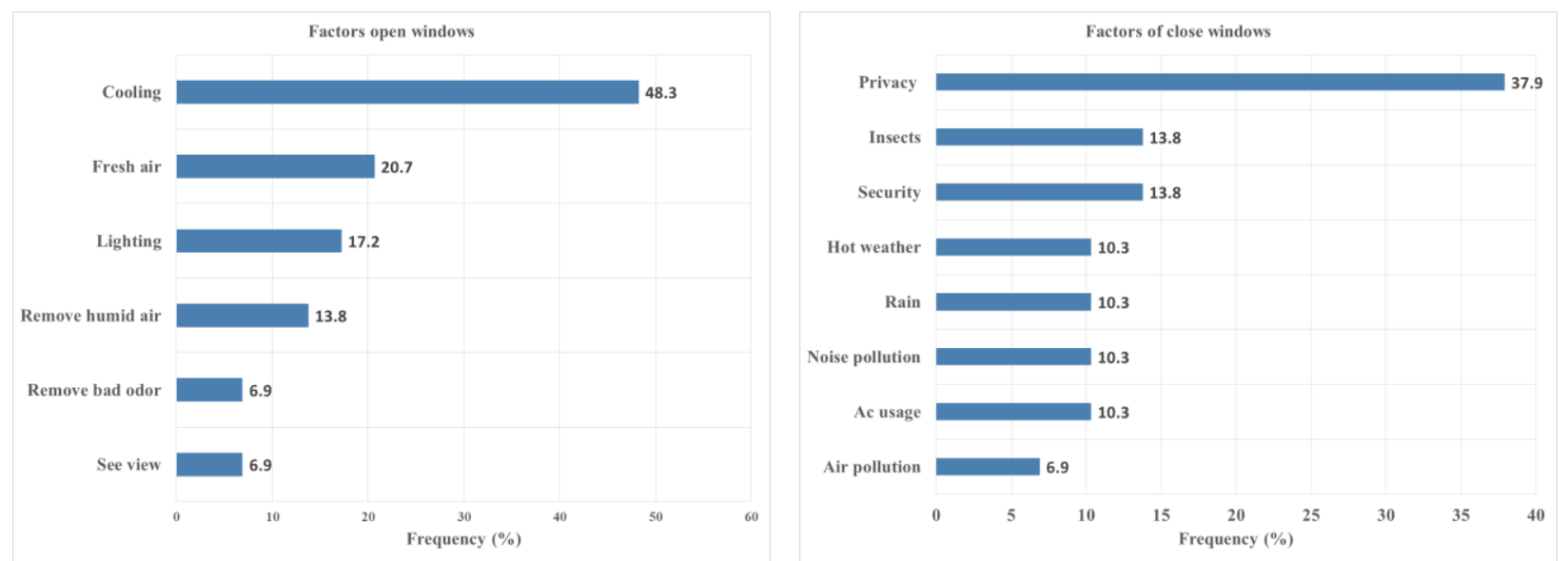

Figure 8 . Factors affecting window opening/ close behaviour

\section{Part IV: General Satisfaction}

Figure 9 shows the level of satisfaction of their respective indoor environment. From seven criteria considered in this questionnaire, most occupants felt neutral for several considerations such as noise (55.2\%) and air pollutions $(58.6 \%)$, airflow and ventilation $(58.6 \%)$, and humidity level $(50.0 \%)$. It is a slightly lower percentage on the "satisfactory level" on the security of windows $(48.3 \%)$ and the amount of natural lighting $(41.4 \%)$. On average, below $30 \%$ of respondents felt dissatisfied with all conditions assessed. Typically, an apartment building's design hardly accommodates all units with the best orientation to minimise the thermal heat gain that affects the thermal comfort, although sufficient opening and sun-shading devices provided.

\section{Part V: Home Appliances}

In this section, the ownership of all home appliances and the use of mechanical cooling was assessed. Figure 10 shows the ownership or installation of fan and AC based on rooms. Fans are mostly installed in the living room $(96.4 \%)$, master bedroom $(92.9 \%)$, bedroom $2(92.9 \%)$ and dining $(78.6 \%)$. The highest $\mathrm{AC}$ installation is at the master bedroom with $67.9 \%$, followed by the living room with $64.3 \%$ and other bedrooms. On average, from 30 dwellings, there are 4 (3.9) fans and 2 (1.9) AC units installed in each dwelling. Unlike in the past, AC usage nowadays is not determined by the higher income group. Regardless of any background, building occupants tend to do whatever possibilities to achieve the best comfort level. 


\section{Preliminary Study of Window-Opening Behaviour and Space Cooling Methods of Urban Households in East Malaysia}

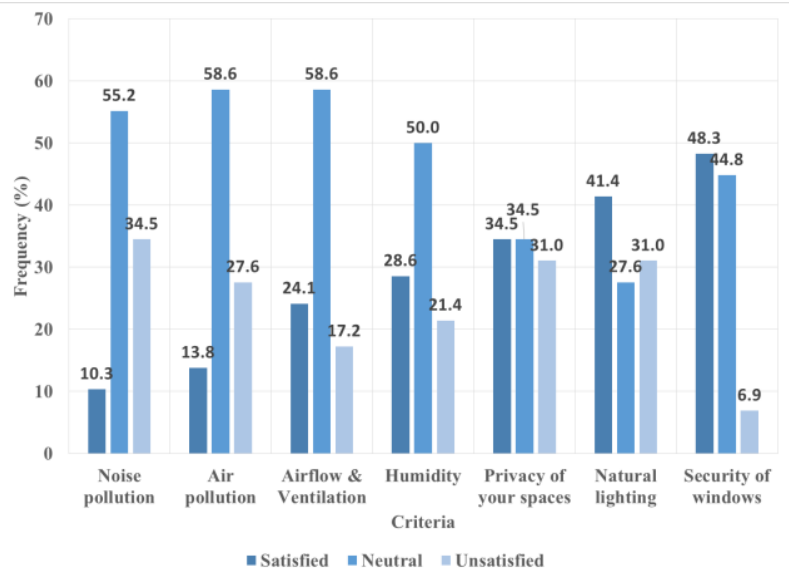

Figure 9. Level of satisfaction of the indoor environment

Figure 11 shows the total number of home appliances owned by the respondents. Most dwellings majorly owned one unit of washing machine $(93.3 \%)$, refrigerator $(90.0 \%)$, vacuum $(76.7 \%)$, microwave and electric kettle $(73.3 \%$ respectively), and cloth iron $(70.0 \%)$. Other appliances such as oven, cloth dryer, and dishwasher have a minor ownership percentage per dwelling of less than $50 \%$ each. However, some respondents have more than one shower water heater, refrigerator, electric kettle, cloth iron, washing machine, and vacuum. About $33.3 \%$ of respondents have two units of a shower water heater installed in their houses based on the total bathroom.

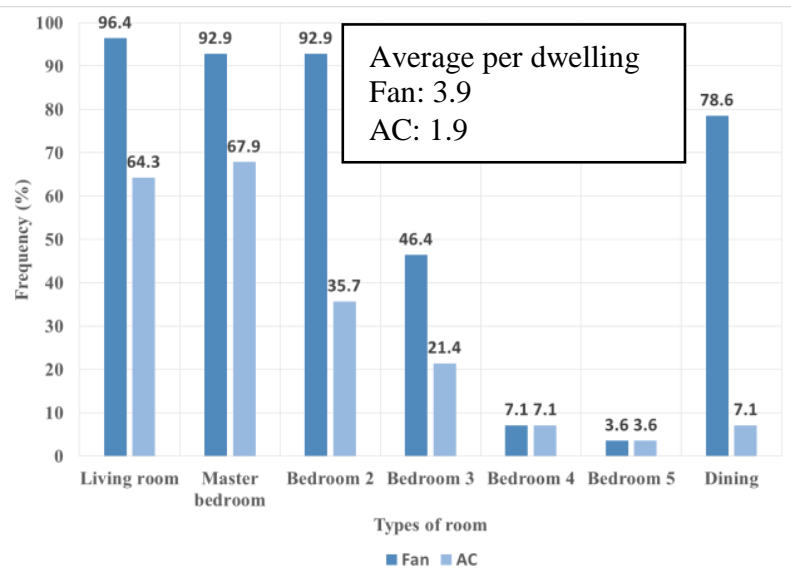

Figure 10. Ownership of fan and AC based on types of room

Based on the US Energy Information Administration (EAI) information, the refrigerator consumed the highest electricity by $14 \%$ and follows by $\mathrm{AC}$, shower water heater, and washing machines. The AC usage is still optional for most occupants in Malaysia compared to the refrigerator and washing machine, considered two necessities in our daily lives. However, this trend is gradually changing as our society is improving their lifestyle daily, consistent with Malaysia's development pace towards a Developed Nation status sooner, thus affecting the total consumption, especially for urban households.

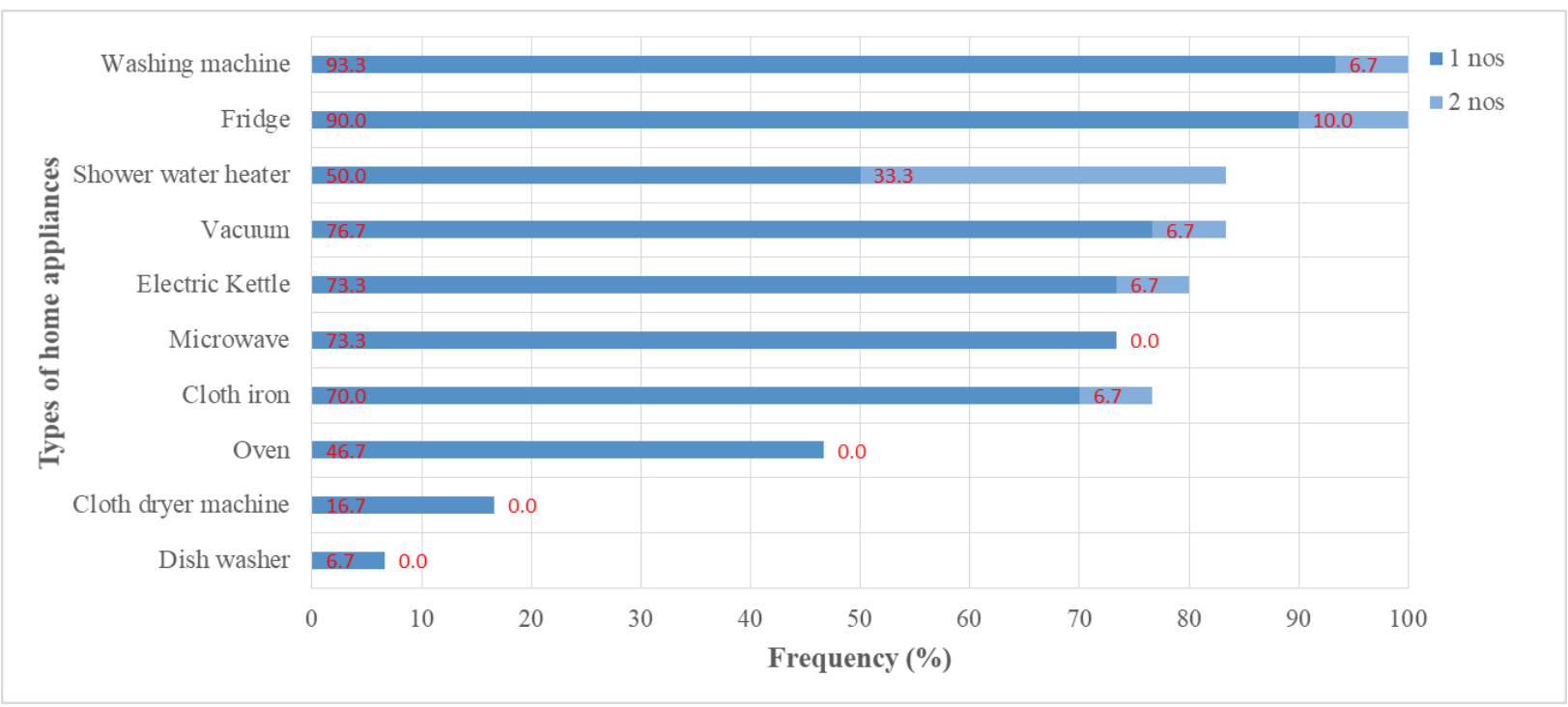

Figure 11. Ownership of other home appliances in all households 


\section{Preliminary Study of Window-Opening Behaviour and Space Cooling Methods of Urban Households in East Malaysia}

\section{CONCLUSION}

This preliminary survey of energy consumption affected by window opening behaviour and space cooling methods in East Malaysia on 30 respondents concluded:

a) Socio-demographic and household types:

- The majority of respondents have a primary or nucleus family type that consists of four households;

- Percentage of working households is higher by $10 \%$ than non-working households;

- Energy consumption was $31.8 \%$ higher than the general usage of an apartment dwelling;

- Household's total consumption was not affected by their income background.

b) House characteristics:

- All dwellings are orientated towards the critical sun exposure of south-east or northwest that make it easier for heat gain, although all of them are installed with appropriate sun-shading devices;

- Occupants used the extra internal protections such as curtains, blinds, and tint film for privacy and further heat gain protection.

c) House occupancy, window opening, and space cooling methods:

- Higher occupancy during nighttime than daytime by $3.9 \%$ as the majority of them are the working households and were not at home during the day;

- Higher occupancy during weekends than weekdays by $1.6 \%$ as most of them prefer to stay at home during weekends;

- The window opening's average duration was 18.6 hours from morning until they went to sleep, where the need to cool the indoor temperature is the main reason. Most of them felt the privacy issue is the main reason they close the window;

- The average AC usage was $38.1 \%$ daily with significant usage during late-night before sleeping hours;

- Fans were used almost throughout the day with an average of $60 \%$;

- The pattern of AC and fan usages is in line with the window opening behaviour.

d) General satisfaction for the living environment:

- Most of the respondents were feeling neutral towards several conditions; noise and air pollutions, airflow and ventilation, and the humidity level;

- They were adequately satisfied with the security of windows and the amount of natural lighting;
- Most of them managed to adapt to their living environment.

e) Home appliances ownership:

- On average, each dwelling installed with four units of fans and two units of $\mathrm{AC}$ where fans are mostly installed in all areas, while AC majorly installed in bedrooms;

- Most dwellings are occupied by the washing machine, refrigerator, vacuum, microwave, electric kettle, and cloth iron, which are considered as the primary home necessities;

- The ownership of these electrical appliances is generally consuming a lot of electricity per usage. The household's behaviour towards use is one of the main contributors affecting the total consumption.

As a preliminary study, the limitation of the total sample size is acknowledged. Thus it will be increased to obtain the more significant behaviour and energy-use pattern for future recommendation. The research should also be extended in the qualitative method to measure a detailed energy-use pattern for urban households.

\section{ACKNOWLEDGMENT}

This research was financially supported by the University Research Grant (UCTS/RESEARCH/3/2017/4) from the University College of Technology Sarawak (UCTS).

\section{REFERENCES}

[1] Arethusa, M. T., Kubota, T., Nugroho, A. M., Antaryama, I. G. N., Ekasiwi, S. N., \& Uno, T. (2014). A field survey of window-opening behaviour and thermal conditions in apartments of Surabaya, Indonesia.

[2] Kavousian, A., Rajagopal, R., \& Fischer, M. (2013). Determinants of residential electricity consumption: Using smart meter data to examine the effect of climate, building characteristics, appliance stock, and occupants' behaviour. Energy, 55, 184-194.

[3] Kubota, T., \& Ahmad, S. (2005). Questionnaire survey on behaviour for natural ventilation and electricity consumption in terraced houses: A case study of Johor Bahru City. In Asian Planning Schools Association (APSA) Conference (pp. 1114).

[4] Zaki, S. A., Hanip, N. F. M., Hagishima, A., Yakub, F., \& Ali, M. S. M. (2018). Survey of resident behaviour related to air conditioner operation in low-cost apartments of Kuala Lumpur. In Chemical Engineering Transactions (pp. 259-264). Italian Association of Chemical Engineering-AIDIC. 
[5] Humphreys, M. A., Rijal, H. B., \& Nicol, J. F. (2013). Updating the adaptive relation between climate and comfort indoors; new insights and an extended database. Building and Environment, 63, 40-55.

[6] Surahman, U., \& Kubota, T. (2012). Development of A Simplified LCA Model For Residential Buildings in Indonesia. AIJ Journal of Technology and Design, 18(40), 1003-1008.

[8] Kubota, T., Jeong, S., Toe, D. H. C., \& Ossen, D. R. (2011). Energy consumption and airconditioning usage in residential buildings in Malaysia. Journal of International Development and Cooperation, 17(3), 61-69.

[9] Google. (2019). Map of Sabah. Retrieved from https://www.google.com.my/maps

[10] Google. (2019). Harrington Suites \& Taman Penampang. Retrieved from https://www.google.com/

[11] Tanimoto, J., \& Hagishima, A. (2010). Total utility demand prediction system for dwellings based on stochastic processes of actual inhabitants. Journal of Building Performance Simulation, 3(2), 155-167.

[12] Fragidis, G., \& Olschewski, D. (2015). Consumer awareness and engagement for energy efficiency solutions. Cleopa White Paper Series.

[13] MALAYSIA, M. M. S. (2016). Department of Statistics, Malaysia

[14] Sarawak Energy Berhad (2020). Residential Energy Tariffs.

[15]Ahmed, M., Mohamed, A., Homod, R., Shareef, H., \& Khalid, K. (2017). Awareness on energy management in residential buildings: A case study in Kajang and Putrajaya. Journal of Engineering Science and Technology, Vol. 12, 1280-1294.

[16]Zaki, S. A., Hagishima, A., Fukami, R., \& Fadhilah, N. (2017). Development of a model for generating air-conditioner operation schedules in Malaysia. Building and Environment, 122, 354-362.

[17] US Energy Information Administration, "US household electricity report 2005" (Washington, DC, US, 2005) 